\title{
NUTRITIONAL VALUE AND HEAVY METALS CONTENTS OF THE DRIED SEA CUCUMBER Stichopus vastus FROM SALEMO ISLAND, INDONESIA
}

\section{KANDUNGAN GIZI DAN LOGAM BERAT TERIPANG KERING Stichopus vastus ASAL PULAU SALEMO, INDONESIA}

\author{
Abdullah Rasyid \\ Research Center for Oceanography - Indonesian Institute of Sciences, Jakarta \\ E-mail: abdu005@lipi.go.id
}

\begin{abstract}
The dried sea cucumber Stichopus vastus is one of the commercially species harvested in Indonesian waters. This study aims to highlight the nutritional value and heavy metals content of dried sea cucumber S. vastus. Proximate (moisture, ash, protein, fat and carbohydrate), mineral (sodium, calcium, potassium and iron) and heavy metal (mercury, cadmium, arsenic and lead) were determined by standard method of AOAC, while phosphorous was determined by spectrophotometric method. Chondroitin sulphate was determined by UPLC method, glucosamine sulphate and vitamin (A, B1, B2 and E) by HPLC method. Results show that protein was the major component in proximate analysis of dried sea cucumber $S$. vastus in the present study. The protein content was $38.70 \%$. Moisture, ash, fat and carbohydrate content were $19.46 \%, 34.04 \%, 0.38 \%$ and $7.42 \%$ respectively. All vitamins and heavy metals examined in this study were not detected. The sodium content was $8054.36 \mathrm{mg} / 100 \mathrm{~g}$ higher than other minerals. Calcium, potassium, phosphorus and iron content were $2449.9 \mathrm{mg} / 100 \mathrm{~g}$, $159.77 \mathrm{mg} / 100 \mathrm{~g}, 5085.2 \mathrm{mg} / 100 \mathrm{~g}$ and $520.8 \mathrm{mg} / 100 \mathrm{~g}$ respectively. Glucosamine sulphate content was found to be $2.429 \mathrm{~g} / 100 \mathrm{~g}$, whereas chondroitin sulphate was found to be $1.115 \mathrm{~g} / 100 \mathrm{~g}$. It can therefore, be concluded that the dried sea cucumber $S$. vastus from Salemo Island is safe for human consumption and hence can be used as a source of food supplement in the future.
\end{abstract}

Keywords: food supplement, Salemo island, Stichopus vastus

\begin{abstract}
ABSTRAK
Teripang kering Stichopus vastus merupakan salah satu jenis teripang komersial yang dipanen dari perairan Indonesia.Penelitian ini bertujuan untuk mengetahui nilai gizi dan logam berat yang terkandung dalam teripang kering $S$. vastus. Penentuan kadar proksimat, mineral dan logam berat menggunakan metode standar AOAC, sedangkan fosfor menggunakan spektrofotometer. Penentuan kadar kondroitin sulfat dengan metode UPLC, sedangkan glukosamin sulfat dan vitamin dengan metode HPLC. Hasil analisis menunjukkan bahwa protein merupakan komponen terbesar dalam analisis proksimat dengan kadar sebesar 38,70\%. Kadar air, abu, lemak dan karbohidrat berturutturut sebesar 19,46\%, 34,04\%, 0,38\% dan 7.42\%. Semua jenis vitamin dan logam berta yang diuji dalam penelitian ini tidak terdeteksi. Natrium merupakan mineral dengan kadar tertinggi sebesar $8054,36 \mathrm{mg} / 100 \mathrm{~g}$. Kadar kalsium, kalium, fosfor dan besi berturut-turut sebesar 2449,9 mg/100 g, $159,77 \mathrm{mg} / 100 \mathrm{~g}, 5085,2 \mathrm{mg} / 100 \mathrm{~g}$ dan 520,8 mg/100 g. Kadar glukosamin sulfat sebesar 2,429 g/100 $\mathrm{g}$, sedangkan kondroitin sulfat sebesar 1,115 g/100 g. Oleh karena itu, dapat disimpulkan bahwa teripang kering S. vastus asal Pulau Salemo aman untuk dikonsumsi dan memiliki potensi sebagai salah satu sumber suplemen makanan di masa depan.
\end{abstract}

Kata kunci: suplemen makanan, pulau Salemo, Stichopus vastus

\section{INTRODUCTION}

Sea cucumbers are holothurian belonging to the phylum Echinodermata, class
Holothuroidea. There are about 1,200 holothurian species in the world (McElroy, 1990). Sea cucumbers have been consumed in Asian countries for centuries for their dietary and 
curative properties (Torai-Granada et al., 2008). As seafood, sea cucumber are usually processed into a dried product known as "beche-de mer" (Fredalina et al., 1999).

Many Asian believe sea cucumber should be eaten to treat ailment such as cancer and arthritis, as well as intestinal and urinary dysfunctions (Purcell, 2010). Sea cucumber and their extract have gained immerse popularity and interest among researchers and nutritionists due to the nutritive value and potential health benefits. It was also used in the treatment of chronic inflammatory diseases. Many areas of the world use sea cucumbers in traditional foods and folk medicine though the actual compounds and their specific functional remain to be still investigated, most sea cucumber extracts are being studied for their anti-inflammatory functions, immune stimulatore properties, and for cancer prevention and treatment (Janakiram et al., 2015).

Sea cucumbers species are commercially exploited fresh or in dehydrated form (beche-de-mer, trepang, gamat) in Asian market, mainly in China, Korea, Indonesia and Japan as functional foods because of their high protein content and their putative aphrodisiac, tonical and medicinal properties. However, some species have been overexploited which may result in a population collapse and the loss of significant potential source of anticancer drug for the future (Perez-Espadas et al., 2014).

Marine invertebrate particularly sea cucumbers belonging to echinoderm have provided impressive useful bioactive compounds such as vitamins, carbohydrates, saponin, sterols and ions with unique biomedical effects such as antimicrobial, antiinflammatory, antioxidant, antifungal, anticancer activities, possess commercial value and consumed as functional food and nutraceutical in traditional medicine (Bordbar et al., 2011).

Sea cucumbers are fished all over the world but abundant in the tropical region (Torai-Granda, 2008). The total annual global catch is in the order of 100,000 tons of live animals annually (Purcell, 2010). The major fisheries exist in china, Ecuador, Indonesia, Japan, Republic of Korea, Malaysia, Philippines, Madagascar, Australia and New Caledonian (Haider et al., 2015).

Sea cucumber Stichopus vastus is one of the family Stichopodidae in the class Holothuroidea. It is commercially harvested in Indonesia, where it is especially common in seashore regions. In the previous study reported that $S$. vastus had an activity as anticancer and wound healing agents (Azemi, 2014; Masre et al., 2010) and radical scavenging (Sukmawati, 2013; Abedina et al., 2014).

In spite of the uncountable benefits of the sea cucumbers, there is no information exists related to dried sea cucumber Stichopus vastus from Salemo Island in terms of their nutritional value and heavy metals content. For this, the present study aims to highlight the nutritional value and heavy metals content of dried sea cucumber $S$. vastus in order to evaluate their quality and their potency for human consumption in the future.

\section{METHODS}

\subsection{Collection Sample}

The dried sea cucumber Stichopus vastus was purchased from the fisher in Salemo island Indonesia. This is ones of the sea cucumber that the majority of fisherman gathered in Salemo island waters. Sea cucumbers are harvested from sea where fishers usually collect it during low tide or dive into the sea. The dried processing was done as below: The sample sea cucumber was gathered in Salemo island waters Indonesia during low tide from the shallow up to deeper parts of the sea. The sample was washed with sea water to remove dirt and sand, and then dissected to remove the internal organ. The sample was collected in the bucket and fully covered salt for three days. Then, sample was cooking in the 
boiling sea water for three hours. Sample was collected in the bucket and fully covered salt for one week. After that, sample was washed with water to remove salt and drying under the sun for several days.

\subsection{Proximate Analysis}

The moisture content (\%) was determined by drying $2 \mathrm{~g}$ sea cucumber $S$. vastus. The sample was put into an oven at $105^{\circ} \mathrm{C}$ and heated for 3 hours. The dried sample was put into desiccator, allowed to cool and reweighed (AOAC, 1980). Ash content (\%) was determined heating sea cucumber $S$. vastus for 4 hours in a muffle furnace at $550^{\circ} \mathrm{C}$ until it turned white and free of carbon. The sample was then removed from the furnace, cooled in a desiccator to a room temperature and reweighed immediately (AOAC, 1980).

Total fat content (\%) was determined by loosely wrapping $2 \mathrm{~g}$ sea cucumber $\mathrm{S}$. vastus with a filter paper and put into the thimble which was fitted to a clean round bottom flask, which has been cleaned, dried and weighed. The flask contained $120 \mathrm{ml}$ of petroleum ether. The sample was heated with a heating mantle and allowed to reflux for 5 hours. The heating then stopped and the thimbles with the spent samples kept and later weighed (AOAC, 1980). Total protein (\%) was calculated from the elemental $\mathrm{N}$ determination using the nitrogen-protein conversion factor of 6.25 according to the standard AOAC method (1980). The carbohydrate content $(\%)$ was estimated by difference: $100-($ moisture + ash + protein + fat) $\%$.

\subsection{Vitamin, Mineral and Heavy Metal Analysis}

Vitamins (A, B1, B2 and E) content were determined by using HPLC (High Performance Liquid Chromatography). For the determination of minerals content (calcium, potassium, iron, and sodium) content was determined by the standard AOAC method (2000). Phosphorus content was determined by spectrophotometric method. While the heavy metals (mercury, cadmium, arsenic and lead) content were determined by the standard AOAC method (1990).

\subsection{Chondroitin Sulphate Analysis}

Chondroitin sulphate analysis with UPLC (Ultra Performance Liquid Chromatography) using apparatus condition: column C18, 250x4.6 mm, $5 \mu \mathrm{m}$ particle size; detector UV with wave length $195 \mathrm{~nm}$; mobile phase octane sulphonic acid: acetonitril: triethylalamine (90.65: 8.96 : 0.381 ); injection volume $20 \mu \mathrm{L}$; Flow rate 1 $\mathrm{mL} / \mathrm{mm}$ and solvent $0.3 \mathrm{~mL}$ acetic acid and 5 $\mathrm{mL}$ acetonitrile in $\mathrm{mL}$ aquadest (destilled water).

Standard solution preparation (Nagarajan et al., 2013): Accurately weighed about $100 \mathrm{mg}$ chondroitin sulphate standard into a $100 \mathrm{~mL}$ volumetric flask and dissolved in 80 $\mathrm{mL}$ of diluent and sonicated for 5 minutes and made up to volume with diluent and homogenised. Pipet $1.00 ; 2.00 ; 3.00 ; 4.00$; 5.00 and $6.00 \mathrm{~mL}$ into $10 \mathrm{~mL}$ volumetric flask and made up to volume with diluent and homogenised. The solution was filtered through $0.45 \mu \mathrm{m}$ filter paper.

Sample preparation: Accurately weighed about 10-15 g sea cucumber $S$. vastus into a $100 \mathrm{~mL}$ volumetric flask and dissolved in $80 \mathrm{~mL}$ of diluent and sonicated for 5 minutes and made up to volume with diluent and homogenised. The solution was filtered through $0.45 \mu \mathrm{m}$ filter paper. Then, $20 \mu \mathrm{L}$ of each of standard and sample solutions were injected into the UPLC system.

\subsection{Glucosamine Sulphate Analysis}

Glucosamine sulphate analysis with HPLC using apparatus condition: Column C$18100 \mathrm{~A}, 5 \mu \mathrm{m}$ particle size; Detector UV with wave length $265 \mathrm{~nm}$; Mobile phase TFA $0.05 \%$ in water with $\mathrm{pH} 2.4$ and Acetonitrile; Injection volume $10 \mu \mathrm{L}$; Flow rate 0.8 $\mathrm{mL} / \mathrm{min}$ and Column temperature $30^{\circ} \mathrm{C}$. 
Standard preparation (AOAC, 2005): About $240 \mathrm{mg}$ standard D (+) glucosamine $\mathrm{HCl}$ was put into $100 \mathrm{~mL}$ volumetric flask and dissolved with $80 \mathrm{~mL}$ aquadest. The solution was sonicated for 5 minutes. TFA $(750 \mu \mathrm{L})$ was added and made up to volume with aquadest and then homogenised. The standard solution $(1 \mathrm{~mL})$ was pipetted into a $100 \mathrm{~mL}$ volumetric flask.

Sample preparation: About $0.5-1 \mathrm{~g}$ sea cucumber $S$. vastus was put into a 100 $\mathrm{mL}$ volumetric flask and dissolved in $80 \mathrm{~mL}$ aquadest. The solution was sonicated for 5 minutes. TFA $(750 \mu \mathrm{L})$ was added and made up to volume with aquadest and then homogenised. The solution was filtered through $0.45 \mu \mathrm{m}$ filter paper.

Derivation procedure: About $125 \mu \mathrm{L}$ of sample solution and $50 \mu \mathrm{L}, 100 \mu \mathrm{L}$ and $200 \mu \mathrm{L}$ of standard solution, respectively, were pipetted into separate $5 \mathrm{~mL}$ volumetric flask. The $500 \mu \mathrm{L}$ of N-9-fluorenylmethoxycarboniloxy succinimide (FMOc-Su) $15 \mathrm{mM}$ was added into each of sample and standard solution and then sonicated for 30 minutes at $50^{\circ} \mathrm{C}$. All solution were cooled at room temperature and made up to volume with mobile phase solution (TFA $0.05 \% \mathrm{pH} 2.4$ : acetonitrile) (1:1) and then homogenized. The solution was filtered through $0.45 \mu \mathrm{m}$ filter paper. Then, $20 \mu \mathrm{L}$ of each of sample and standard solutions were injected into the HPLC system.

\section{RESULTS AND DISCUSSION}

\subsection{Proximate Composition}

The proximate composition including moisture, ash, protein, fat, and carbohydrate of the dried sea cucumber Stichopus vastus from Salemo island waters Indonesia is shown in Table 1. In this study, the moisture content was $19.46 \%$ dry weight base. This result is relatively low compared with the quality standard of commercial dried sea cucumber sold in Indonesia set by the National Standardization Agency of Indonesia, where the moisture standard of the dried sea cucumber was $20 \%$ dry weight base (SNI 2732.1 :2009). This result was higher than other species of sea cucumber base on the dry weight such as $S$. hrrmanni (10.2\%), Thelenota ananas (15.1\%), $T$ anax (1.2\%), Holothuria fuscogilva (11.6\%), H. fuscopunctata (7.0\%), Actinopyga mauritiana (11.6\%), A. caerulea (0.81\%), Bohadschia argus (13.0\%) (Wen et al., 2010), Parastichopus spp. (2-6\%) (Chang-Lee et al., 1989), P. californicus (4.03\%) (Bechtel et al., 2013), H. scabra (12.13\%) (Sroyraya et al., 2017), H. atra (9.9\%), H. echinites (9.3\%) and H. scabra (8.2\%) (Ibrahim et al., 2015) and H. tubulosa (16.19\%) (Sicuro et $a l ., 2012)$. The result was lower than reported by Sicuro et al. (2012) for H. polii (22.03\%),

Table 1. Nutrient content of dried sea cucumber Stichopus vastus.

\begin{tabular}{|c|c|c|}
\hline No & Parameter & $\begin{array}{c}\text { Result } \\
\text { (Dry Weight) }\end{array}$ \\
\hline 1 & Moisture (\%) & 19.46 \\
\hline 2 & Ash (\%) & 34.04 \\
\hline 3 & Protein $(\%)$ & 38.70 \\
\hline 4 & Fat $(\%)$ & 0.38 \\
\hline 5 & $\begin{array}{l}\text { Carbohydrate } \\
(\%)\end{array}$ & 7.42 \\
\hline 6 & $\begin{array}{l}\text { Vitamin A } \\
(\mathrm{mcg} / 100 \mathrm{~g})\end{array}$ & Not detected \\
\hline 7 & $\begin{array}{l}\text { Vitamin B1 } \\
(\mathrm{ppm})\end{array}$ & Not detected \\
\hline 8 & $\begin{array}{l}\text { Vitamin B2 } \\
(\mathrm{ppm})\end{array}$ & Not detected \\
\hline 9 & $\begin{array}{l}\text { Vitamin E } \\
(\mathrm{mg} / 100 \mathrm{~g})\end{array}$ & Not detected \\
\hline 10 & $\begin{array}{l}\text { Sodium } \\
(\mathrm{mg} / 100 \mathrm{~g})\end{array}$ & 8054.36 \\
\hline 11 & $\begin{array}{l}\text { Calcium } \\
(\mathrm{mg} / 100 \mathrm{~g})\end{array}$ & 2449.9 \\
\hline 12 & $\begin{array}{l}\text { Potassium } \\
(\mathrm{mg} / 100 \mathrm{~g})\end{array}$ & 159.77 \\
\hline 13 & $\begin{array}{l}\text { Phosphorus } \\
\text { (mg/100 g) }\end{array}$ & 5085.2 \\
\hline 14 & $\begin{array}{l}\text { Iron } \\
(\mathrm{mg} / 100 \mathrm{~g})\end{array}$ & 520.8 \\
\hline
\end{tabular}


The ash content of sea cucumber $S$. vastus examined in this study was $34.04 \%$ dry weight base. This result was lower than other species of sea cucumber base on the dry weight such as S. hermanni (37.9\%), T anax (39.2\%), $H$. fuscopunctata (39.6\%) (Wen et al., 2010), H. tubulosa (46.43\%) and H. polii (48.22\%) (Sicuro et al., 2012). The result in this study higher than $T$. ananas (25.1\%) H. fuscogilva (26.4\%), A. mauritiana $(15.4 \%)$, A. caerulea $(0.81 \%)$, B.argus (17.7\%) (Wen et al., 2010), Parastichopus spp. (16-24\%) (Chang-Lee et al., 1989), $P$. californicus (25.73\%) (Bechtel et al., 2013), H. scabra (27.97\%) (Sroyraya et al., 2017), H. atra $(31.58 \%)$, H. echinites $(29.25 \%)$ and H. scabra (22.02\%) (Ibrahim et al., 2015). The ash content which may be the result from the mineral deposit in the body wall of sea cucumber $S$. vastus.

Protein was the major component in the proximate composition of $S$. vastus examined in the present study. The protein content in the dried sea cucumber $S$. vastus examined in this study was found to be $38.7 \%$ dry weight base. This result was lower than other species of sea cucumber base on the dry weight such as $S$. hermanni $(47.0 \%)$, T. ananas (55.2\%), $T$ anax (40.7\%), $H$. fuscogilva (57.8\%), H. fuscopunctata (50.10\%), A. mauritiana (63.3\%), A. caerulea (56.9\%), B.argus (62.1\%) (Wen et al., 2010), Parastichopus spp. (61-70\%) (Chang-Lee et al., 1989), P. californicus (47.03\%) (Bechtel et al., 2013), H. scabra (55.18\%) (Sroyraya et al., 2017), H. atra $(58.2 \%), H$. echinites (60.2\%) and H. scabra (68.67\%) (Ibrahim et al., 2015), H. tubulosa (44.58\%) (Sicuro et al., 2012 but lower than H. polii $(36.99 \%)$ (Sicuro et al., 2012).

The fat content of the dried sea cucumber $S$. vastus examined in this study was $0.38 \%$ dry weight base. This result was similar to other species base on the dry weight reported by Wen et al (2010) for $H$. fuscogilva $(0.3 \%)$ and $H$. fuscopunctata $(0.3 \%)$. The result was examined in this study lower than other species in the previous study base on the dry weight such as Parastichopus spp. (2-3\%) (Chang-Lee et al. (1989), P. californicus (8.19\%) (Bechtel et al., 2013), S. hermanni (0.8\%), T. ananas (1.9\%), T anax (9.9\%), A. mauritiana (1.4\%), A. caerulea (10.1\%), B.argus (1.1\%) (Wen et al., 2010), H. scabra (1.02\%) (Sroyraya et al., 2017), H. scabra (1.02\%) (Sroyraya et al., 2017), $H$. atra (1.32\%), H. echinites (1.25\%) and H. scabra (1.11\%) (Ibrahim et al., 2015).

The carbohydrate content of the dried sea cucumber $S$. vastus examined in this study was found to be $7.42 \%$ dry weight base. This result was higher than other species base on the dry weight such as reported by Chang-Lee et al. (1989) for Parastichopus spp. was 2-3\%, by Wen et al. (2010) for S. hermanni (4.1\%), T. ananas (2.7\%), H. fuscogilva (3.9\%) A. mauritiana (6.3\%) and A. caerulea (3.79\%), H. scabra (3.7\%) (Sroyraya et al., 2017). The result was found in this study similar to reported by Wen et al. (2010) for B.argus (7.1\%) and by Ibrahim et al. (2015) for H. atra (7\%) base on the dry weight. This result was lower than other species as base on the dry weightreported by Bechtel et al. (2013) for $P$. californicus (15.02\%), by Wen et al. (2010) T anax (9\%) and $H$. fuscopunctata (9\%),

\subsection{Vitamin Content}

All vitamins examined in this study such as vitamin $\mathrm{A}, \mathrm{B} 1, \mathrm{~B} 2$ and $\mathrm{E}$ were not detected. In the previous study, vitamin A was not detected in the H. scabra but vitamin E was detected in H. scabra $(4.94 \mathrm{mg} / 100 \mathrm{~g})$ (Sroyraya et al., 2017).

The undetectable vitamins tested in this study are likely to result from the processing of dried sea cucumber $S$. vastus by heating with boiling water. In previous research showed that fresh sea cucumber $S$. vastus contain vitamin $\mathrm{A}, \mathrm{B} 1$ and $\mathrm{B} 2$ (Ardiansyah and Rasyid, 2016). As it is known that the vitamin in the food will be lost by heating. 


\subsection{Mineral Content}

The mineral composition examined in this study included, sodium (Na), calcium $(\mathrm{Ca})$, potassium $(\mathrm{K})$, phosphorus $(\mathrm{P})$ and iron $(\mathrm{Fe})$ is shown in Table 2. The sodium was the major component in the mineral analysis of the dried sea cucumber $S$. vastus in the present study. The sodium content was 8,054.36 mg/100 g. Calcium, potassium, phosphorus and iron were $2,449.9 \mathrm{mg} / 100 \mathrm{~g}$, $159.77 \mathrm{mg} / 100 \mathrm{~g}, 5085.2 \mathrm{mg} / 100 \mathrm{~g}$ and 520.8 $\mathrm{mg} / 100 \mathrm{~g}$ respectively.

In the previous study reported that calcium was the major component in the $H$. arenicola followed sodium. In the other hand, sodium was the major component in the A. mauritiana followed calcium (Haider et al., 2015), similarly to $P$. californicus (Bechtel et al., 2013). According to Diniz et al. (2012), the chemical composition of marine organisms in general may be influenced by a number of factors such as physiological characteristics, habitat and life cycle, and environmental conditions.

\subsection{Heavy Metals Content}

The heavy metal content examined in this study is shown in Table 2. All heavy metals examined in this study included mercury $(\mathrm{Hg})$, lead $(\mathrm{Pb})$, cadmium $(\mathrm{Cd})$ and arsen (As) were not detected.

Table 2. Heavy metal content of dried sea cucumber Stichopus vastus.

\begin{tabular}{crrc}
\hline No & $\begin{array}{r}\text { Heavy } \\
\text { metal }\end{array}$ & $\begin{array}{r}\text { Result } \\
(\mathrm{ppm})\end{array}$ & $\begin{array}{c}\text { SNI } \\
(\mathrm{ppm})\end{array}$ \\
\hline 1 & Mercury & $\begin{array}{l}\text { Not } \\
\text { detected }\end{array}$ & $<1,0$ \\
2 & Lead & $\begin{array}{l}\text { Not } \\
\text { detected }\end{array}$ & $<1,5$ \\
3 & Cadmium & $\begin{array}{l}\text { Not } \\
\text { detected } \\
\text { Not } \\
\text { detected }\end{array}$ & $<1,0$ \\
4 & Arsenic & \begin{tabular}{l}
$<1,0$ \\
\hline
\end{tabular}
\end{tabular}

In Indonesia, the quality criteria applied to the dried sea cucumber according to the National Standardization Agency of Indonesia (SNI 7387 : 2009), where the upper limit for arsenic, cadmium and mercury were less than $1 \mathrm{mg} / \mathrm{Kg}$, while the upper limit for lead was less than $1.5 \mathrm{mg} / \mathrm{Kg}$. The result in this study showed that the dried sea cucumber $S$. vastus was within the feasible based on the qualification criteria for the dried sea cucumber sold in Indonesia.

Some of the heavy metals such as arsenic (As), copper $(\mathrm{Cu})$, iron $(\mathrm{Fe})$, manganese $(\mathrm{Mn})$ and zinc $(\mathrm{Zn})$ are essential micronutrients but when present in excess cause toxicity, whereas lead $(\mathrm{Pb})$ and cadmium (Cd) are well known toxic metals which create certain medical condition when present in excessive levels in organisms and consumed by human being (Fraga, 2005).

\subsection{Glucosamine Sulphate and Chondroitin Sulphate}

Glucosamine sulphate and chondroitin sulphate were found to be $2.439 \mathrm{~g} / 100 \mathrm{~g}$ and $1.115 \mathrm{~g} / 100 \mathrm{~g}$ each other (Table 3 ).

Table 3. Glucosamine sulphate and chondroitin sulphate of dried sea cucumber Stichopus vastus.

\begin{tabular}{clc}
\hline No & \multicolumn{1}{c}{ Parameter } & $\begin{array}{c}\text { Result } \\
(\mathrm{g} / 100 \mathrm{~g})\end{array}$ \\
\hline 1 & $\begin{array}{l}\text { Glucosamine } \\
\text { sulphate }\end{array}$ & 2.439 \\
2 & $\begin{array}{l}\text { Chondroitin } \\
\text { sulphate }\end{array}$ & 1.115 \\
\hline
\end{tabular}

Glucosamine sulphate was primary biological role in halting or reversing joint degeneration appears to be directly due to its ability as an essential substrate to stimulate the biosynthesis of the glycosaminoglycans and the hyaluronic acid. The backbone was needed for the formation of proteoglycans in the structural matrix. Chondroitin sulphate, whether they are absorbed intact or broken into their constituent components, similarly provide additional substrates for the formation of a healthy joint matrix. Evidence 
also supports the oral administration of chondroitin sulphate for joint disease, both as an agent to slowly reduce symptoms and reduce the need of non-steroidal antiinflammatory drugs. The combined of glucosamine sulphate and chondroitin sulphate in the treatment of degenerative joint disease has become an extremely popular supplementation protocol in arthritic conditions of the joints. Glucosamine sulphate and chondroitin sulphate are often administered together (Kelly, 1998).

\section{CONCLUSION}

The protein value was significant and the fat was low observed in the dried sea cucumber $S$. vastus from Salemo Island. The major mineral content were sodium, phosphorus and calcium respectively. Heavy metals determined in this study were not detected. It can be concluded that the dried sea cucumber $S$. vastus is safe for human consumption and hence can be used as source of food supplement in the future.

\section{ACKNOWLEGEMENT}

Author wish to acknowledge the financial support from the Budget Implementation Registration Form of Research Center for Oceanography, Indonesian Institute of Sciences.

\section{REFERENCES}

Abedina, M.Z., A.A. Karima, A.A. Latiffb, C.Y. Ganc, F.C. Ghazalid,Z. Barzideha, S. Ferdosha, M.J.H. Akandaa, W. Zzamana, M.R. Karime and M.Z.I. Sarkerf. 2014. Biochemical and radical-scavenging properties of sea cucumber (Stichopus vastus) collagen hydrolysates. Natural Product Research., 28(16):1302-1305.

Ardiansyah, A. and A. Rasyid. 2016. Evaluation on the nutrition and heavy metal contents of fresh sea cucumber,
Stichopus vastus. Prosiding Pertemuan Ilmiah Nasional Tahunan XII ISOI 2015. Ikatan Sarjana Oseanologi Indonesia, Jakarta. 159-166pp.

Association of Official Analytical Chemist (AOAC). 1980. Official methods of analysis $12^{\text {th }}$ ed. Virginia. AOAC Inc. USA. 1018p.

Association of Official Analytical Chemist (AOAC), 2000, Official methods of analysis $7^{\text {th }}$ ed. Washington D.C. $1026 \mathrm{p}$.

Association of Official Analytical Chemist (AOAC). 2005 Official method of analysis $18^{\text {th }}$ ed. Washington D.C. 1045p.

Bechtel, P.J., A.C.M. Oliveira, N. Demir, and S. Smiley. 2013. Chemical composition of the giant red sea cucumber, Parastichopus californicus, commercially harvested in Alaska. Food Science and Nutrition, 1(1):63-73.

Bordbar, S., F. Anwar, and N. Saari. 2011. High-value components and bioactive from sea cucumbers for functional foods. Marine Drugs, 9:1761-1805.

Chang-Lee, M.V., R.J. Price and L.E. Lampila.1989. Effect of processing on proximate composition and mineral content of Sea Cucumbers (Parastichopus spp.). J. of Food Science, 54(3):567-568.

Diniz, G.S., E. Barbarino, and S.O. Lourenço. 2012. On the chemical profile of marine organisms from coastal subtropical environments: Gross composition and nitrogen to protein Conversion Factors. Oceanography. USA. 320p.

Fraga, C.G. 2005. Relevance, essentiality and toxicity of trace elements in human health. Molecular Aspect of Medicine, 26:235-244.

Fredalina, B.D., B.H. Ridzwan, A.A.Z Abidin, M.A. Kaswandi,H. Zaiton, I. Zali, P. Kittakoop and A.M.M. Jais. 1999. Fatty acid composition in local 
sea cucumber Stichopus chloronotus for wpund healing. Gen. Pharmacol, 33(4):337-340.

Haider, M.S., R. Sultana, K. Jamil, Lakht-eZehra, O.M. Tarar, K. Shirin and W. Afzal. 2015. A study on proximate composition, amino ac Id profile, fatty acid profile, and some mineral contents in two species of sea cucumber. The J. of Animal and Plant Sciences, 25(1):168-175.

Ibrahim, M.Y., S.M. Elamin, Y.B.A. Gideiri and S.M. Ali. 2015. The proximate composition and the nutritional value of some sea cucumber species inhabiting the sudanese red sea. Food Science and Quality Management, 41:11-16.

Janakiram, N.B., A. Mohammad, and C.V. Rao. 2015. Sea cucumbers metabolites as potent anticancer agents. Mar. Drugs, 13:2909-2923.

Kelly, G.S. 1998. The role of glucosamine sulphate and chondroitin sulphates in the treatment of degenerative joint desease. Altern. Med. Rev., 3(1):2739.

Masre, S.F., G.W. Yip, K. Sirajudeen and F.C. Ghazali. 2010. Wound healing activity of total sulphated glycosaminoglycan (GAG) from Stichopus vastus and Stichopus hermanni integumental tissue in rats. Int. J. Mol. Med., 6:49-53.

Nagarajan, P, S.K. Dinakaran, S. Ghosh, H. Avasarata, M. Nallayya and D. Banji. 2013. Method development and validation of glucosamine and chondroitin sulphate in soflet form by RPHPLC. Research and Reviews, J. of Pharmaceutical Analysis, 2(3): 6-10.

Nurul, A.A. 2014. Potential of Stichopus horrens and Stichopus vastus extracts as anticancer and wound healing agents: Effects on breast cancer and fibroblast cell lines. Universiti Sains Malaysia. Malaysia. 192p.
Perez-Espadas, A.R., M.J. Verde-Star, C. Rivas-Morates, A. Oranday-Cardenas, M. E. Morales-Rubio, L.V. Leon-Deniz, J. Canul-Canche and L. Quijano. 2014. In vitro cytotoxic activity of Isostichopus badionotus, a sea cucumber from Yucatan Peninsula coast. J. of Pharmacy and Nutrition Sciences, 4:183-186.

Purcell, S.W. 2010. Managing sea cucumber fisheries with and ecosystem approach. FAO fisheries and aquaculture technical. Food and Agriculture Organization of the United Nations. Rome, Italy. 26p.

Torai-Granada, V., A. Lovatelli, and M. Vasconcellos. 2008. Fisheries and aquaculture technical. Food and Agriculture Organization of the United Nations. Rome, Italy. 282p.

Sicuro, B., M. Piccinno, F. Gai, M.C. Abete, A. Danieli, F. Dapra, S. Mioletti, and S. Vilella. 2012. Food quality and safety of Mediterranean sea cucumber Holothuria tubulosa and Holothuria polii. Asian J. Anim. Vet., 7(9):851859.

Sroyraya, M., P.J. Hanna, T. Siangeham, B. Tinikul, P. Jatiujan, T. Poomtong and P. Sobhon. 2017. Nutritional components of the sea cucumber Holothuria scabra. Functional Food in Health and Disease., 7(3):168-181.

Sukmiwati, M. 2013. Uji aktivitas antioksidan pada 16 spesies teripang yang ditemukan pada perairan Natuna, Kepulauan Riau. http://repository. unri.ac.id:80/handle/123456789/3523. [Retrieved on 30 November 2017].

Wen, J., C. Hu, and S. Fan 2010. Chemical composition and nutritional quality of sea cucumbers. J. Sci. Food Agric., 90:2469-2474.
Diterima
: 23 Mei 2017
Direview : 26 Juni 2017
Disetujui : 30 November 2017 